\title{
Comparison of Detection Methods for a Novel Tobamovirus Isolated from Florida Hibiscus
}

Ivanka Kamenova and Scott Adkins, United States Department of Agriculture, Agricultural Research Service, United States Horticultural Research Laboratory, Fort Pierce, FL 34945

\begin{abstract}
Kamenova, I., and Adkins, S. 2004. Comparison of detection methods for a novel tobamovirus isolated from Florida hibiscus. Plant Dis. 88:34-40.

A novel tobamovirus recently was isolated from hibiscus in Florida. Serological and molecular methods, including enzyme-linked immunosorbent assay (ELISA), dot-blot immunoassay (DBIA), tissue-blot immunoassay (TBIA), and immunocapture reverse-transcription polymerase chain reaction (IC-RT-PCR) were compared to evaluate their usefulness for diagnosis of this virus. Each method was tested with partially purified virus preparations and tissue samples from infected hibiscus and Chenopodium quinoa plants. Indirect ELISA was more sensitive than double-antibody sandwich (DAS)-ELISA with all samples tested. The Florida hibiscus virus was detectable in hibiscus leaves and bark up to 1:12,800 and 1:6,400 dilutions, respectively, by indirect ELISA and up to 1:3,200 and 1:400 dilutions by DAS-ELISA. End-point dilutions of partially purified virus preparations from indirect and DAS-ELISA were 4 and $31 \mathrm{ng} / \mathrm{ml}$, respectively. Florida hibiscus virus was detected by DBIA in sap from hibiscus bark and leaves at dilutions up to 1:400 and 1:800, respectively, showing that DBIA was less sensitive than either ELISA method. The virus also was detected reliably by TBIA from leaves and bark of hibiscus plants. The most sensitive method was IC-RT-PCR, which could detect as little as $500 \mathrm{pg} / \mathrm{ml}$ of virus in partially purified preparations and was 16- and 32-fold more sensitive than DAS-ELISA with hibiscus bark and leaf extracts, respectively. Over 600 hibiscus samples were tested by various combinations of these methods to validate their usefulness.
\end{abstract}

A putative tobamovirus has been isolated recently from hibiscus (Hibiscus rosa-sinensis) in Florida landscape plantings (1). Virion morphology and genome organization are consistent with it being a tobamovirus. Comparison of the coat protein $(\mathrm{CP})$ gene with $\mathrm{CP}$ sequences of recognized tobamoviruses revealed only 45 to $53 \%$ nucleotide identity, and $68 \%$ nucleotide identity with the $\mathrm{CP}$ gene of another putative tobamovirus recently isolated from hibiscus in Singapore $(1,19)$. The host range of the Florida hibiscus virus mostly is limited to the Malvaceae, which includes food and fiber crops such as okra, cotton, and kenaf, in addition to economically important ornamentals like hibiscus. An initial survey for the distribution of the Florida hibiscus virus in landscape plants in Florida has shown a high level $(56 \%)$ of incidence (1).

Hibiscus and many of its relatives are vegetatively propagated. This important horticultural practice, however, is also a very effective method for plant infection

Corresponding author: S. Adkins

E-mail: SAdkins@ushrl.ars.usda.gov

Accepted for publication 22 August 2003.

Publication no. D-2003-1105-02R

This article is in the public domain and not copyrightable. It may be freely reprinted with customary crediting of the source. The American Phytopathological Society, 2004. and virus spread. Indexing of stock plants for elimination of virus-infected plants prior to propagation is a key element of disease management and requires the application of sensitive and reliable detection methods.

Biological methods for plant virus detection and diagnosis include inoculation of indicator plants, a technique used since the early days of plant virology. These bioassay procedures are labor intensive and frequently require considerable time for symptom development. Technical difficulties often are encountered when bioassaying viruses from woody perennial plants on herbaceous indicator plants, as observed with the Florida hibiscus virus (1). Serologically based tests commonly are employed today because of their specificity in disease diagnosis and relative ease of completion. Serological methods widely used in plant virology include enzyme-linked immunosorbent assay (ELISA), dot-blot immunoassay (DBIA), immunospecific electron microscopy, and tissue-blot immunoassay (TBIA) $(4,5,12,14,16)$. Detection methods based on reverse-transcription polymerase chain reaction (RTPCR) also have been used frequently for detection of RNA plant viruses $(7,10)$. An RT-PCR-based method in which viral RNA is prepared directly from antibody-captured virus particles (IC-RT-PCR) was described for the detection of Plum pox virus (PPV; 22) and later adopted for other plant viruses $(15,18)$.
We report the development and application of ELISA, DBIA, TBIA, and IC-RTPCR procedures for detection of the Florida hibiscus virus. A direct comparison of the sensitivity of these methods was made to evaluate their usefulness for diagnosis of this virus. The rapidity, ease, and sensitivity of these methods for the diagnosis of infected plants makes them amenable for routine testing to index stock plants as a general management plan to decrease the propagation of virus-infected hibiscus plants.

\section{MATERIALS AND METHODS}

Virus sources. The original virus isolate collected from hibiscus plants in Florida (1) has been maintained by mechanical inoculation of Chenopodium quinoa, using $20 \mathrm{mM}$ sodium phosphate buffer $(\mathrm{pH} 7.0)$ containing $1 \%(\mathrm{wt} / \mathrm{vol})$ Celite. Naturally infected landscape plants and hibiscus cuttings also were used as virus sources. A Florida isolate of the tobamovirus Pepper mild mottle virus (PMMoV; 2) was maintained by the same method in Nicotiana tabacum cv. Xanthi. Virions were isolated from inoculated leaves of $C$. quinoa (Florida hibiscus virus) or upper, uninoculated leaves of N. tabacum cv. Xanthi (PMMoV) essentially as described by Wetter and Conti (21). Extinction coefficients of $\mathrm{E}_{260 \mathrm{~nm}}{ }^{0.1 \%}=3.00$ (Florida hibiscus virus) and $\mathrm{E}_{260 \mathrm{~nm}}{ }^{0.1 \%}=3.18(\mathrm{PMMoV})$ were used to estimate virus concentration spectrophotometrically (21).

Leaves from infected $C$. quinoa plants; leaves, bark, and roots from infected hibiscus plants; or partially purified virus preparations were used to evaluate diagnostic techniques.

Purification and enzyme conjugation of Immunoglobulin-G. Immunoglobulin$\mathrm{G}$ (IgG) fractions from polyclonal rabbit antiserum to the Florida hibiscus virus (1) were purified by ammonium sulfate precipitation as described by Clark and Adams (4). $\mathrm{IgG}$ at a concentration of $1 \mathrm{mg} / \mathrm{ml}$ was conjugated with 2,000 units of alkaline phosphatase (Roche Molecular Biochemicals, Indianapolis, IN) as described by Avrameas (3). IgG was stored with $0.05 \%$ (wt/vol) sodium azide and the conjugate was stored with $1 \%(\mathrm{wt} / \mathrm{vol})$ bovine serum albumin, both at $4^{\circ} \mathrm{C}$.

DAS-ELISA. A DAS-ELISA protocol was developed for detection of the Florida hibiscus virus using standard protocols (4) as previously described (1). Briefly, the 
plates were coated with $\operatorname{IgG}(100 \mu \mathrm{l}$ of 1 $\mu \mathrm{g} / \mathrm{ml}$ per well) diluted in $0.05 \mathrm{M}$ sodium carbonate buffer ( $\mathrm{pH}$ 9.6). Tissue was homogenized in sample buffer consisting of phosphate-buffered saline (PBS, $0.14 \mathrm{M}$ $\mathrm{NaCl}, 1 \mathrm{mM} \mathrm{KH} \mathrm{PO}_{4}, 8 \mathrm{mM} \mathrm{Na} \mathrm{HPO}_{4}$, $2.5 \mathrm{mM} \mathrm{KCl}, \mathrm{pH} 7.4$ ) containing $0.5 \%$ (vol/vol) Tween-20, 2\% (wt/vol) polyvinylpyrrolidone, and $0.2 \%$ (wt/vol) ovalbumin. Homogenate $(100 \mu \mathrm{l}$ per well) was incubated overnight at $4{ }^{\circ} \mathrm{C}$ followed by conjugated IgG (1:1,000 dilution in sample buffer, $100 \mu$ l per well) with incubation for $3 \mathrm{~h}$ at $37^{\circ} \mathrm{C}$.

Indirect ELISA. Indirect ELISA was performed using antigen-coated plates as described by Koenig (11). Plant samples were prepared in $0.05 \mathrm{M}$ sodium carbonate buffer ( $\mathrm{pH}$ 9.6) and incubated at $4^{\circ} \mathrm{C}$ overnight, followed by $100 \mu \mathrm{l}$ of virus-specific IgG $(1 \mu \mathrm{g} / \mathrm{ml})$ in PBS containing $0.5 \%$ (vol/vol) Tween-20 (PBST) with incubation for $2 \mathrm{~h}$ at $37^{\circ} \mathrm{C}$. Alkaline phosphataseconjugated goat anti-rabbit IgG $(100 \mu \mathrm{l}$ of 1:3,000 dilution in PBST; Bio-Rad, Hercules, CA) was added for $2 \mathrm{~h}$ at $37^{\circ} \mathrm{C}$.

Cocktail ELISA. The same buffers and samples used in DAS-ELISA were used for cocktail ELISA (6). Plates were coated with $\mathrm{IgG}$ (at a concentration of $1 \mu \mathrm{g} / \mathrm{ml}$ ) by incubation for $3 \mathrm{~h}$ at $37^{\circ} \mathrm{C}$. Then, $100 \mu \mathrm{l}$ of each sample and $100 \mu \mathrm{l}$ of alkaline phosphatase-conjugated Florida hibiscus virusspecific IgG were added to the wells simultaneously (total volume $200 \mu \mathrm{l}$ ) and incubated overnight at $4^{\circ} \mathrm{C}$.

Polystyrene microtiter plates (\#9018; Costar, Cambridge, MA) were used for all ELISA assays. Plates were washed three times with PBST between each step. Controls in all ELISA assays included sample buffer only, and uninfected and virus-infected plant tissue. Absorbance at $405 \mathrm{~nm}$ was measured with an MRX Revelation microplate reader (Thermo Labsystems, Chantilly, VA) about 60 to $90 \mathrm{~min}$ after the addition of the substrate ( $p$-nitrophenyl phosphate). A threshold value for positive samples was set at three times the value of the uninfected control.

DBIA and TBIA. Polyvinylidene difluoride (PVDF) membranes (Amersham Biosciences Corp., Piscataway, NJ) were pre-wet in $100 \%$ methanol for $10 \mathrm{~s}$ and then washed in distilled water for $1 \mathrm{~min}$. For DBIA, the membranes were marked into $1-\mathrm{cm}$ squares and a $2-\mu \mathrm{l}$ sample (homogenized in PBST) was spotted in the center of each square. For TBIA, several leaves (two to three) first were rolled into a tight bundle before being cut with a sterile razor blade. Petioles were cut transversely, whereas small pieces of bark were cut vertically along the length of the stem. Freshly cut edges of all tissues were pressed firmly against the membrane. Membranes for both assays were placed in heat-sealable plastic bags and blocked with $5 \%$ (wt/vol) nonfat dry milk (NFDM) in PBS buffer for $1 \mathrm{~h}$ with gentle shaking at room temperature. After a brief rinse in PBST, the membranes were incubated with virus-specific $\operatorname{IgG}$ at $1 \mu \mathrm{g} / \mathrm{ml}$ in PBST with gentle agitation at room temperature for 1 h. Membranes were washed in three changes of PBS, including $0.5 \%$ (wt/vol) NFDM for $10 \mathrm{~min}$ each, then incubated with alkaline phosphatase-conjugated goat anti-rabbit IgG (AP-GAR; Bio-Rad), or with horseradish peroxidase-conjugated goat anti-rabbit IgG (HR-GAR; Bio-Rad) at 1:3,000 dilutions in PBST for $1 \mathrm{~h}$ at room temperature. Membranes were washed as described above and dried for a short time between filter paper.

Two detection systems were used for membranes treated with AP-GAR secondary antibodies. For colorimetric detection, membranes were incubated in a freshly prepared substrate solution containing 5bromo-4-chloro-3-indolyl phosphate (BCIP) at $0.15 \mathrm{mg} / \mathrm{ml}$ and nitro blue tetrazolium (NBT; Sigma-Aldrich, St. Louis, MO) at $0.30 \mathrm{mg} / \mathrm{ml}$. For fluorescent detection with AP-GAR antibodies, membranes were incubated in ECF detection reagents (Amersham Biosciences) and visualized using a Molecular Dynamics Storm 840 imaging system (Amersham Biosciences). For chemiluminescent detection with HR-GAR antibodies, membranes were incubated in ECL detection reagents (Amersham Biosciences) and exposed to X-ray film.

IC-RT-PCR. Sterile 0.6-ml polypropylene microcentrifuge tubes were coated with $100 \mu \mathrm{l}$ of Florida hibiscus virus-specific $\operatorname{IgG}(1 \mathrm{mg} / \mathrm{ml}$ diluted $1: 1,000$ in 0.05 $\mathrm{M}$ sodium carbonate buffer, $\mathrm{pH}$ 9.6), incubated for $3 \mathrm{~h}$ at $37^{\circ} \mathrm{C}$ and washed three times with PBST at $200 \mu \mathrm{l} /$ tube. Plant tissues were homogenized in ELISA sample buffer and centrifuged at $10,000 \times g$ for $10 \mathrm{~min}$ at $4^{\circ} \mathrm{C}$. Dilutions of the supernatant and virion preparations were made and $100-\mu \mathrm{l}$ aliquots were added to the coated tubes. The tubes were incubated overnight at $4{ }^{\circ} \mathrm{C}$ and washed three times with PBST at $200 \mu \mathrm{l} /$ tube. Florida hibiscus virusspecific primers flanking the deduced $\mathrm{CP}$ gene (1) were used. The viral sense primer (5'-GACACAGAGAAATCTGGGGCAG$\left.3^{\prime}\right)$ is identical to the nucleotide sequence just upstream of the $5^{\prime}$ terminus and the viral complementary sense primer (5'TTAGTTAGCAGGAGCGGTCCA-3') is complementary to nucleotides 457 to 477 at the $3^{\prime}$ terminus of the deduced CP gene (GenBank accession no. AY250831). Firststrand cDNA was synthesized by Moloney murine leukemia virus reverse transcriptase (200 U/ $\mu$ l; Promega Corp., Madison, WI) at $47^{\circ} \mathrm{C}$ for $45 \mathrm{~min}$ in the manufacturer's buffer. Thirty cycles of PCR amplification with $\mathrm{Taq}$ polymerase $(5 \mathrm{U} / \mu \mathrm{l}$; Promega Corp.) at $94^{\circ} \mathrm{C}$ for $1 \mathrm{~min}, 59^{\circ} \mathrm{C}$ for $1 \mathrm{~min}$, and $72^{\circ} \mathrm{C}$ for $1 \mathrm{~min}$ and $30 \mathrm{~s}$ in the manufacturer's buffer followed the first-strand synthesis. The predicted length of the amplified DNA product is $535 \mathrm{bp}$. Products were analyzed by electrophoresis on native
$2 \%$ agarose gels and detected by ethidium bromide staining.

Application of diagnostic techniques. To validate their usefulness, indirect ELISA, DAS-ELISA, and TBIA were used to test over 600 leaf samples from Florida landscape and greenhouse hibiscus plants. Samples consisted of 6-mm leaf disks homogenized in sample (DAS-ELISA) or sodium carbonate (indirect ELISA) buffer at a ratio of 1:25 (wt/vol). TBIA leaf samples were prepared and blotted as described above.

\section{RESULTS}

Development of serological detection assays. The sensitivity of indirect and DAS-ELISA for detection of the Florida hibiscus virus was compared using endpoint dilutions of sap from different plant tissues (all samples were divided and assayed by each method) and partially purified virus preparations. End-point dilutions were defined in at least three comparable assays performed at different times. Results from this experiment indicated that indirect ELISA was more sensitive than DAS-ELISA for the detection of the virus in all tested samples (Fig. 1). Positive reactions with sap from infected $C$. quinoa leaves diluted 1:51,200 and 1:6,400 were obtained by indirect ELISA and DASELISA, respectively (Fig. 1A and B), indicating that indirect ELISA was approximately eightfold more sensitive than DASELISA. Detection limits for the Florida hibiscus virus in leaf and bark extracts from hibiscus plants by indirect ELISA were $1: 12,800$ and $1: 6,400$, respectively (Fig. 1A); whereas, by DAS-ELISA, detection limits were at a dilutions of 1:3,200 and 1:400, respectively (Fig. 1B). Thus, for detection of virus in leaves and bark, indirect ELISA was 4- and 16-fold more sensitive, respectively, than DAS-ELISA. The sensitivity of indirect and DAS-ELISA tests was similar with extracts from hibiscus roots at higher dilutions (from 1:800 to 1:3,200; Fig. 1A and B). However, the absorbance values obtained with DASELISA were twice the absorbance values obtained with indirect ELISA at lower root sap dilutions (1:25, 1:50 and 1:100). With DAS-ELISA, it was not possible to detect the virus in the roots at dilutions higher than 1:1,600 (Fig. 1B); whereas, by indirect ELISA, the detection limit was at a dilution of 1:3,200 (Fig. 1A). The current levels of detection of partially purified virus preparations by DAS- and indirect ELISA were 31 and $4 \mathrm{ng} / \mathrm{ml}$, respectively (Fig. 1C). No cross-reaction with partially purified preparations of $\mathrm{PMMoV}$ was observed with either indirect or DAS-ELISA.

The standard 2-day indirect and DASELISA tests were compared with abbreviated procedures requiring only 1 day. Each incubation step was reduced to $2 \mathrm{~h}$ at $37^{\circ} \mathrm{C}$. The results (not shown) from 1-day ELISA by either method were unchanged from 
those of overnight incubation of the antigen in the 2-day ELISA procedures. The virus was detected reliably in leaf samples from hibiscus plants, with the shorter indi- rect and DAS-ELISA methods providing results in 6 to $7 \mathrm{~h}$.

The usefulness of cocktail ELISA for detection of the Florida hibiscus virus was
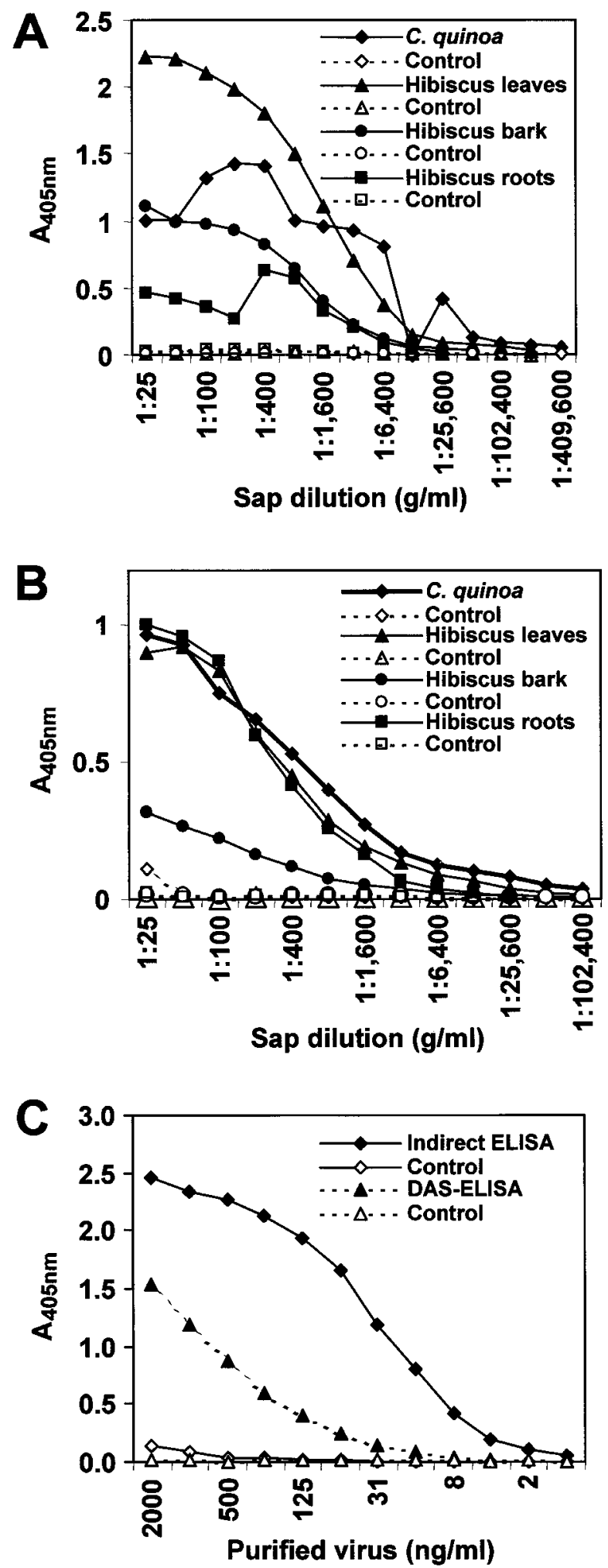

Fig. 1. Detection limits of Florida hibiscus virus by indirect and double-antibody sandwich (DAS) enzyme-linked immunosorbent assay (ELISA) methods. A, Indirect ELISA with sap from infected and uninfected (control) Chenopodium quinoa leaves and hibiscus leaves, bark, and roots. B, DAS-ELISA with samples as in A. C, Indirect and DAS-ELISA with partially purified virus preparations where control is Pepper mild mottle virus. In all assays, twofold dilutions were made with sodium carbonate (indirect ELISA) or sample (DAS-ELISA) buffer. End-point dilutions were defined in at least three comparable assays performed at different times. Average absorbance values $\left(A_{405 \mathrm{~nm}}\right)$ are presented. studied with sap from infected and uninfected $C$. quinoa leaf samples. With all dilutions prepared from infected tissues, the absorbance values obtained by cocktail ELISA were 3 to 4 times less than the absorbance values obtained from DASELISA, and 10 times lower than the values obtained from indirect ELISA (results not shown). The absorbance values in cocktail ELISA were slightly enhanced when $0.13 \%$ sodium sulfite (wt/vol) was added to the sample buffer, but the same effect was obtained with DAS-ELISA, too. The addition of $0.2 \%(\mathrm{wt} / \mathrm{vol})$ ethylendiaminetetraacetic acid to the sample buffer reduced the absorbance values of infected samples in both cocktail ELISA and DASELISA methods.

DBIA. DBIA was sensitive to an endpoint dilution of $1: 12,800$ with sap extracted from infected $C$. quinoa leaves (Fig. 2A). Florida hibiscus virus was detected in sap from infected hibiscus leaves and bark at dilutions of 1:800 and 1:400, respectively (Fig. 2B and C). The level of detection by DBIA was $125 \mathrm{ng} / \mathrm{ml}$ of purified virus preparation (Fig. 2D). No background reaction was seen with extracts from uninfected $C$. quinoa or hibiscus plants, or PMMoV virions.

TBIA. Florida hibiscus virus was detected readily in tissue blots from infected leaves, both from $C$. quinoa and hibiscus plants (Fig. 3A and B). When the membranes were developed in BCIP/NBT substrate solution, the presence of the virus in blots from infected tissues was evidenced by the development of intense purple color (Fig. 3A and B). The tissue blots from uninfected leaves did not show virusspecific purple color, although some plant pigments remained visible on the membranes. Florida hibiscus virus also was detected readily in tissue blots from infected bark and leaves using HR-GAR secondary antibodies and developed with the ECL detection system (Fig. 3C and D). The use of ECL avoided pigmentation issues (and appeared to have less background) because the membranes were not examined directly.

We also tested direct TBIA by probing the blotted membranes with only virusspecific alkaline phosphatase-conjugated IgG. This direct detection was suitable for the Florida hibiscus virus and no difference in the sensitivity between the indirect and direct TBIA methods was noted (data not shown).

To determine if blotted membranes could be stored and processed later, they were kept for 10 days at room temperature. No difference in the intensity of the reaction of the stored membranes was noted when compared with membranes processed immediately after blotting.

IC-RT-PCR detection. Using partially purified virus preparations or crude extracts of infected $C$. quinoa and hibiscus plants, products of the expected size of 535 
bp were observed in agarose gels following IC-RT-PCR amplification (Fig. 4A). No amplification products from uninfected $C$. quinoa or hibiscus plants were obtained. The sensitivity of IC-RT-PCR for virus detection was determined from serial dilutions of partially purified preparations and virus-infected plant tissue homogenate. Amplification products with purified virus preparations were obtained with as little as $500 \mathrm{pg} / \mathrm{ml}$ (50 pg/100 $\mu \mathrm{l}$ reaction; Fig. 4B). The detection limit for infected $C$. quinoa extracts was at a dilution of $1: 102,400$. The detection limits from infected hibiscus leaves and bark were at dilutions of 1:51,200 and 1:12,800, respectively (Table 1 ).

The detection limits of IC-RT-PCR and DAS-ELISA were compared (Table 1). Using partially purified virus preparations, IC-RT-PCR was 62-fold more sensitive than DAS-ELISA. IC-RT-PCR showed 16fold greater sensitivity than DAS-ELISA for detection of the Florida hibiscus virus in leaf extracts from both infected $C$. quinoa and hibiscus and 32-fold higher sensitivity with bark extracts.

Virus distribution within landscape and greenhouse plants. Whole branches from infected landscape and greenhousegrown hibiscus plants were tested by indirect and DAS-ELISA methods. The samples included five leaf discs from each leaf of the branch, bark, and different parts of the flower (petals, stamens, and ovaries). Indirect and DAS-ELISA detection yielded identical results for all tissue types tested. The virus was detected in the bark of all hibiscus plants. However, different patterns of virus distribution were noted in the leaves of landscape and greenhouse plants. In landscape hibiscus plants, the virus concentration was higher in the younger leaves (from the top part of the branch) than in the older leaves (from the lower and middle parts of the branches), although all leaves contained virus. In these plants, the virus also was detected in petals and stamens. ELISA results for virus presence in the flowers were confirmed with bioassays on $C$. quinoa. Typical Florida hibiscus virus chlorotic local lesions developed 7 to 10 days after inoculation and the identity of the virus was confirmed by DASELISA.

Restricted virus distribution in the leaves of several greenhouse-grown plants of hibiscus cv. Pink Versicolor and two experimental lines (5308 and 1302) was found. In all infected plants, the virus was detected in the oldest leaves on the branches. The virus was not detectable by ELISA in the leaves from the middle and top parts of the branches. No virus was detected in any flower parts. Florida hibiscus virus always was present, however, in the roots of greenhouse-grown plants, thus confirming these tissues as a reliable source for virus detection.

Application of the techniques. An important aspect of this investigation was the application of some of the detection methods to large numbers of leaf samples. DAS-ELISA results from the first large test showed that 12 of 189 samples $(6.3 \%)$ from Pink Versicolor, 3 of 113 samples (2.6\%) from Brilliant Red, 1 of 9 samples (11\%) from 1302 , and 3 of 13 samples (23\%) from 5308 reacted positively for the Florida hibiscus virus.

In a second large test, DAS-ELISA and TBIA were compared for detection of the Florida hibiscus virus. More than 300 leaf samples from commercially propagated Pink Versicolor, Brilliant Red, and experimental hibiscus line 8911 were tested. All samples were negative for virus presence when tested by DAS-ELISA. However, four samples from Brilliant Red and seven samples from 8911 were positive when tested by TBIA. Indirect ELISA confirmed these 11 positive results.

\section{DISCUSSION}

Accurate identification is the first step in successful management of any pathogen. This is especially important for previously unknown pathogens like the Florida hibiscus virus. Although several basic diagnostic methods are in use for many previously characterized plant virus diseases, each method must be evaluated for its suitability when testing for a new virus. The objective of our study was to compare and optimize serological and molecular assays that per-
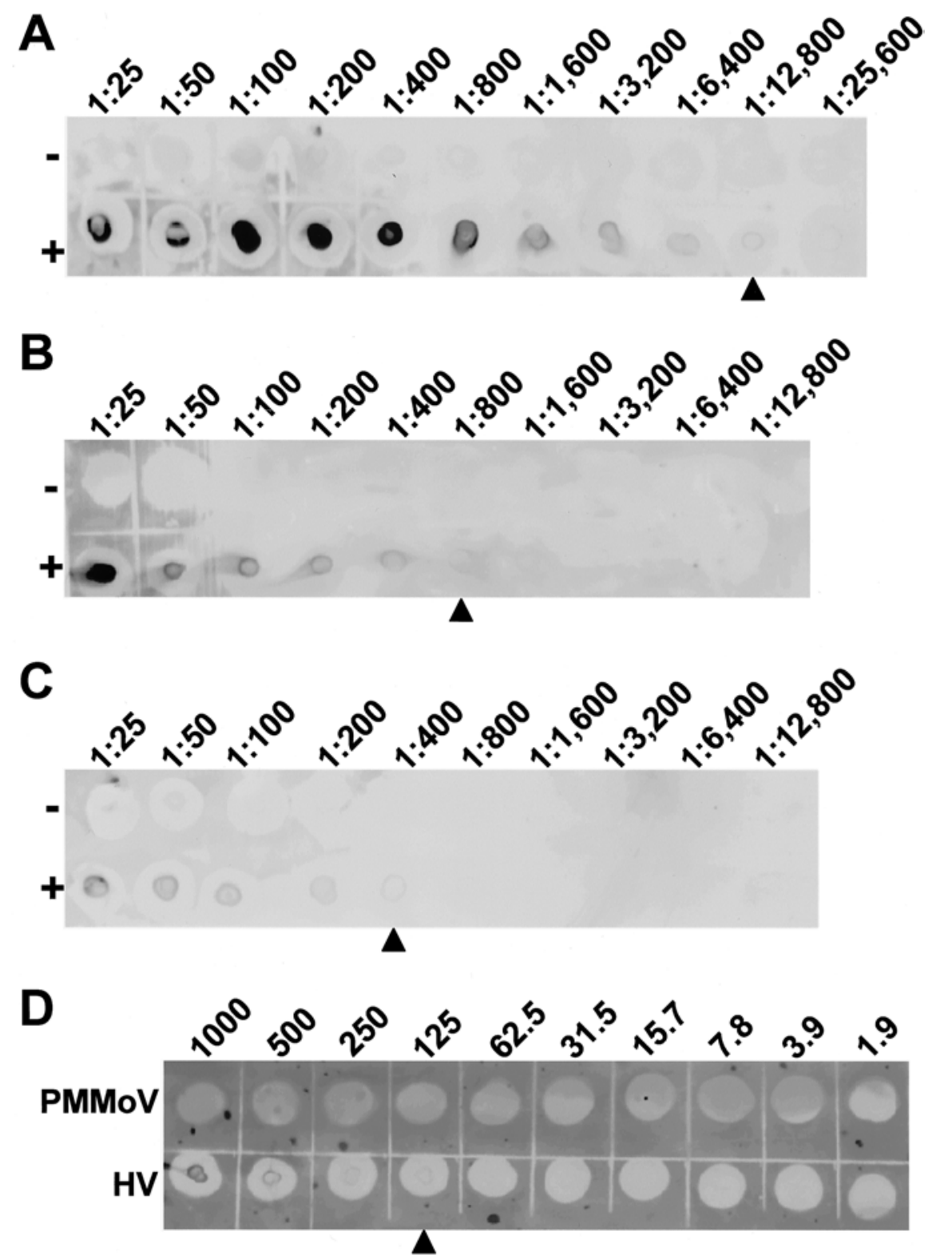

Fig. 2. Detection limits of Florida hibiscus virus by dot-blot immunoassay (DBIA). End-point dilutions of extracts from uninfected (-) and infected (+) A, Chenopodium quinoa leaves, B, hibiscus leaves, $\mathbf{C}$, hibiscus bark, and $\mathbf{D}$, partially purified virus preparations of Pepper mild mottle virus (PMMoV) and Florida hibiscus virus (HV). Blots were developed with ECF detection reagents (Amersham Biosciences) and scanned with a Molecular Dynamics Storm 840 at $450 \mathrm{~nm}$. Dilutions of plant samples (A, B, and C) and nanograms of virus (D) are shown above the blots. Detection limits are indicated with triangles. 
mit sensitive and reliable detection of the Florida hibiscus virus.

We have compared and evaluated indirect, DAS-, and cocktail-ELISA procedures with various hibiscus tissues and partially purified virus preparations. Indirect ELISA had a greater sensitivity than either DAS- or cocktail-ELISA. The observed high sensitivity of indirect ELISA compared with DAS-ELISA could be due
A<smiles>[13CH3]</smiles><smiles>[CH]</smiles>
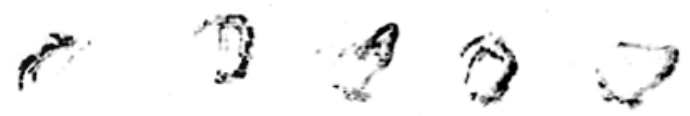

$=$
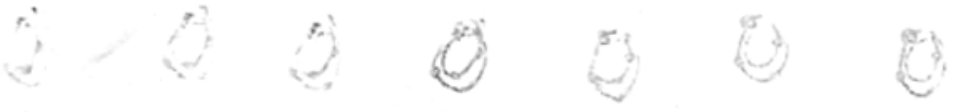

B
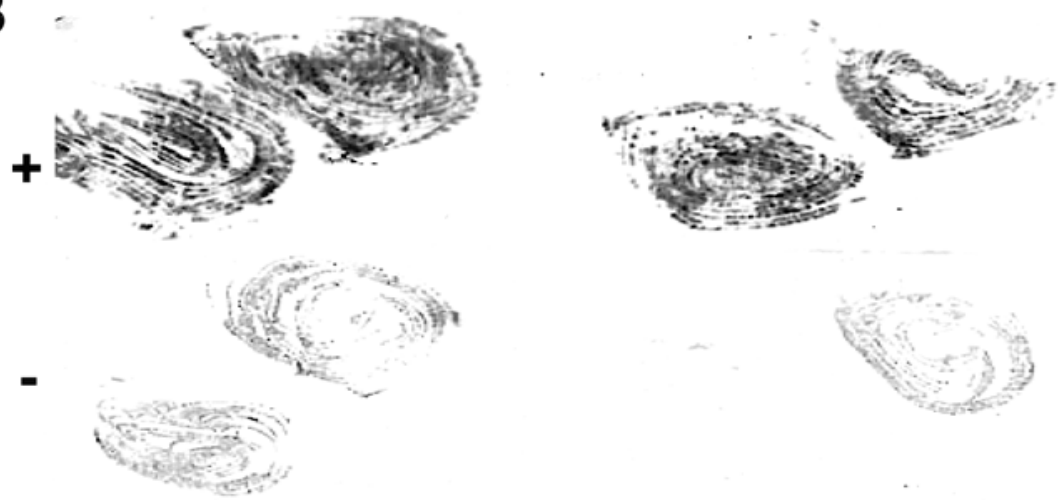

C

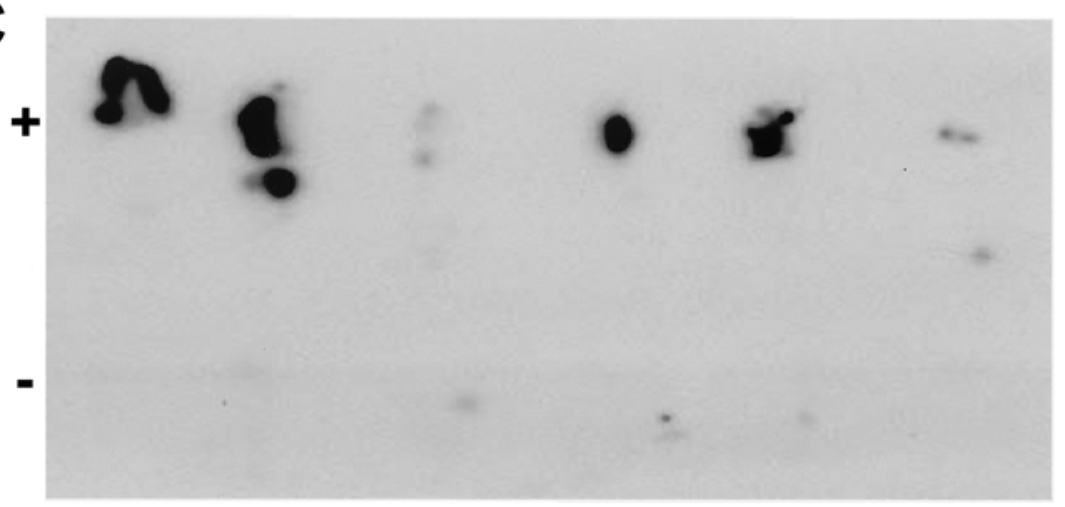

D

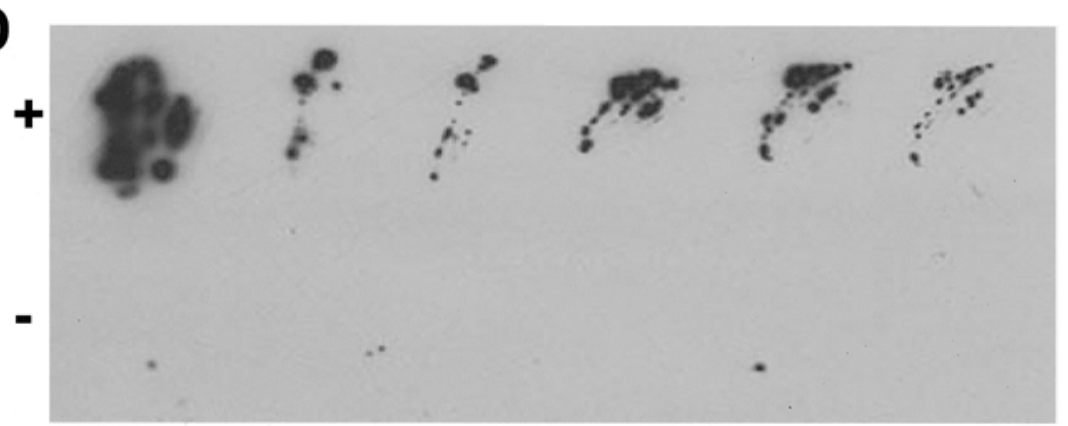

Fig. 3. Detection of Florida hibiscus virus by tissue-blot immunoassay in infected (+) and uninfected (-) A, Chenopodium quinoa leaves, B, hibiscus leaves, $\mathbf{C}$, hibiscus bark from a single branch, and $\mathbf{D}$, hibiscus leaves. Primary antibody for all blots was Florida hibiscus virus-specific polyclonal antibody. Secondary antibody for blots A and B was alkaline phosphatase goat anti-rabbit Immunoglobulin-G (IgG). Secondary antibody for blots $C$ and D was horseradish peroxidase-conjugated goat antirabbit IgG. Blots A and B were developed with 5-bromo-4-chloro-3-indolyl phosphate and nitro blue tetrazolium. Blots C and D were developed with ECL detection reagents (Amersham Biosciences). to the binding of more virus antigen on plates that were not precoated with specific antibodies, as suggested by Hsu and Aebig and cited by Hsu and Lawson (9). Although cocktail-ELISA is less time consuming than indirect or DAS-ELISA, this procedure was not sensitive enough and, therefore, not suitable for detection of the Florida hibiscus virus.

When evaluating the sensitivity of indirect and DAS-ELISA, their relative ability for accurate quantitation of viral antigens in crude extracts should be considered. For instance, we observed an increase in absorbance values by indirect ELISA with increasing dilutions of $C$. quinoa leaves and hibiscus roots (Fig. 1A). This likely reflects competition between viral and plant proteins for the finite number of binding sites on the microtiter plate, as previously observed by Lommel et al. (13). This implies that indirect ELISA is not the best method for accurate quantitation of viral antigens at low sample dilutions.

In the evaluation of the merits and sensitivity of indirect and DAS-ELISA, their relative ability for cross-reaction with related plant viruses also should be considered. Serological studies with several tobamoviruses have shown that even distantly related strains have been detected by indirect ELISA, whereas closely related strains have not been detected by DASELISA (20). Thus, a concern of applying indirect ELISA for routine testing for the Florida hibiscus virus is the possibility of detecting other, related tobamoviruses. For example, a sample from another woody, perennial ornamental (infected with a yetunidentified virus) reacted positively with Florida hibiscus virus-specific antiserum in indirect ELISA but negatively in DASELISA. Additionally, during our second large test, 11 hibiscus plants were positive by indirect ELISA and TBIA but negative by DAS-ELISA, suggesting the presence of a different tobamovirus in these plants. Therefore, DAS-ELISA would be preferred for specific detection of the Florida hibiscus virus, for instance, in virus surveys where a definitive identification is required. However, indirect ELISA may be more applicable in indexing programs where the goal is elimination of all viruses.

DBIA has been used routinely for detection and diagnosis of many plant viruses in the Cucumovirus, Luteovirus, Potexvirus, Potyvirus, and Tospovirus genera $(9,16)$. For detection of the Florida hibiscus virus, we compared DBIA (Fig. 2) with indirect and DAS-ELISA methods. Both ELISA procedures were more sensitive than DBIA, likely due to a greater affinity of the antigen for the polystyrene ELISA plates than the PVDF membrane.

TBIA was first described by Lin et al. (12) for detection of several viruses and phytoplasmas. Our results demonstrated that TBIA was sufficiently sensitive for detection of the Florida hibiscus virus and 
was useful with both leaf and bark samples (Fig. 3). Unlike ELISA methods, TBIA provided information on the distribution of the virus in infected leaves and bark. TBIA also was faster and less labor intensive, because the prints on the membranes could be made in only a few minutes, making it suitable for large-scale tests. In addition, we stored blotted membranes for 10 days at room temperature without any loss in sensitivity. This makes TBIA a very convenient method because the prints could be made in the field and then sent to a diagnostic laboratory for testing.

Our results with DBIA and TBIA showed that the Florida hibiscus virus was reliably detected not only with the use of the AP-GAR enzyme system but also with the HR-GAR conjugate (Figs. 2 and 3). The presence of peroxidases and oxidizing substances in many plant species frequently makes HR-GAR less suitable in plant virology (8), but no difference in the sensitivity between these two enzymes and ECF and ECL detection systems was noted for Florida hibiscus virus detection. Both detection reagents, however, require a laboratory equipped with special detection apparatus, whereas the membranes incubated with AP-GAR and developed with BCIP/NBT substrate can be processed without any expensive instruments.

IC-RT-PCR was the most sensitive of the techniques studied for detection of the

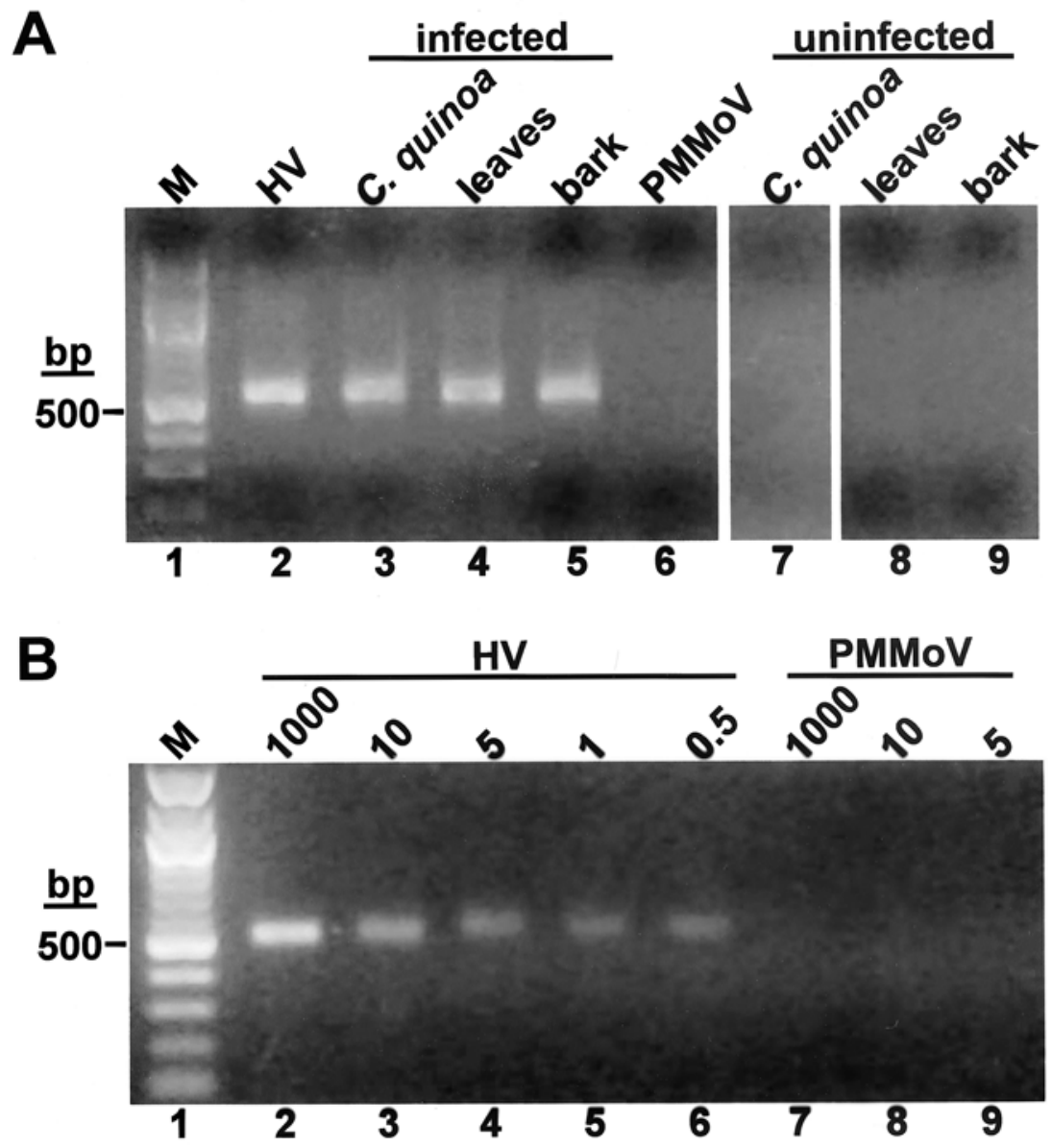

Fig. 4. Detection of Florida hibiscus virus by immunocapture reverse-transcription polymerase chain reaction (IC-RT-PCR). A, Samples of partially purified Florida hibiscus virus (HV, lane 2) and Pepper mild mottle virus (PMMoV, lane 6) preparations, infected and uninfected Chenopodium quinoa leaves (lanes 3 and 7), hibiscus leaves (lanes 4 and 8), and hibiscus bark (lanes 5 and 9) were amplified by IC-RT-PCR with specific primers, analyzed by native electrophoresis on a $2 \%$ agarose gel, and stained with ethidium bromide. Lane 1 contains markers with size in base pairs (bp) indicated to the left of the gel. B, Detection limit of Florida hibiscus virus by IC-RT-PCR using partially purified virus preparations. Amounts of virions assayed are indicated in nanograms above the gel. Abbreviations and markers are as in $\mathrm{A}$.

Florida hibiscus virus, as previously observed for other viruses $(15,17,18,22)$. ICRT-PCR allowed detection of purified Florida hibiscus virus at $500 \mathrm{pg} / \mathrm{ml}(50 \mathrm{pg} / 100$ $\mu \mathrm{l}$; Fig. 4). Readily detectable amplification products were observed at such high dilutions as 1:51,200 and 1:12,800 of infected leaf and bark homogenates, respectively.

The reliability of tissue type for detection of the Florida hibiscus virus should be considered before the selection of a detection method. Analyses of the bark from both landscape and greenhouse plants revealed that the virus always was present in that tissue, thus making it a reliable virus source. However, we observed irregular distribution of the virus in bark from a single branch (Fig. 3C), and we also observed a difference in the distribution of the virus between the landscape and greenhouse plants. In the landscape plants, the virus was detectable in leaves at all locations along the branches; whereas, in the greenhouse plants, a more restricted virus distribution was observed. The virus was detected only in the oldest leaves at the base of the branches (and never in the youngest leaves at the top of the branches) in the greenhouse plants. This observation may be related to plant age or cultivar because the landscape plants were 2 to 3 years old and the greenhouse grown plants were less than 1 year old. We suggest that, when leaves are used for virus testing, at least four to five older leaves per plant should be combined into a single sample to ensure more reliable virus detection.

Application of the techniques described and compared here should be especially useful in routine indexing, clean-stock programs, and epidemiological studies for the Florida hibiscus virus. ELISA techniques as well as TBIA, given their simplicity and relatively small labor requirement, readily available reagents, and applicability to large numbers of samples are more convenient and practical. However, with its high sensitivity and the need for only small quantities of infected tissue, IC-RT-PCR could be considered as a useful alternative to ELISA and TBIA for Florida hibiscus virus detection in cases where sample size is limited or the virus concentration is low.

\section{ACKNOWLEDGMENTS}

We thank C. Vanderspool, H. Capobianco, and K. Cerveny for their excellent technical assistance; B. Reddick for providing culture virus-indexed hibiscus cuttings; and M. E. Hilf and D. J. Lewandowski for valuable discussion and critical reviews of the manuscript.

Table 1. Detection limits of immunocapture reverse-transcription polymerase chain reaction (IC-RT-PCR) and double-antibody sandwich enzyme-linked immunosorbent assay (DAS-ELISA) for Florida hibiscus virus

\begin{tabular}{lcccc}
\hline & & \multicolumn{2}{c}{ Sap dilutions } \\
\cline { 3 - 5 } Method & Virions & Chenopodium quinoa leaves & Hibiscus leaves & Hibiscus bark \\
\hline IC-RT-PCR & $500 \mathrm{pg} / \mathrm{ml}$ & $1: 102,400$ & $1: 51,200$ & $1: 12,800$ \\
DAS-ELISA & $31 \mathrm{ng} / \mathrm{ml}$ & $1: 6,400$ & $1: 3,200$ & $1: 400$ \\
\hline
\end{tabular}




\section{LITERATURE CITED}

1. Adkins, S., Kamenova, I., Achor, D., and Lewandowski, D. J. 2003. Biological and molecular characterization of a novel tobamovirus with a unique host range. Plant Dis. 87:1190-1196

2. Adkins, S., Lamb, E. M., Roberts, P. D., Gooch, M. D., Breman, L., and Shuler, K. D. 2001. Identification of Pepper mild mottle virus in commercial bell pepper in Florida. Plant Dis. 85:679.

3. Avrameas, S. 1969. Coupling of enzymes to proteins with glutaraldehyde. Immunochemistry 6:43-52.

4. Clark, M. F., and Adams, A. N. 1977. Characteristics of the micro plate method of enzymelinked immunosorbent assay for the detection of plant viruses. J. Gen. Virol. 34:475-483.

5. Derrick, K. S. 1973. Quantitative assay for plant viruses using serologically specific electron microscopy. Virology 56:652-653.

6. Flegg, C. L., and Clark, M. F. 1979. The detection of apple chlorotic leafspot virus by a modified procedure of enzyme-linked immunosorbent assay (ELISA). Ann. Appl. Biol. 91:61-65.

7. Henson, J. M., and French, R. 1993. The polymerase chain reaction and plant disease diagnosis. Annu. Rev. Phytopathol. 31:81109.

8. Hsu, H. T., Hibino, H. and Cabautan, P. Q.
1990. Development of serological procedures for rapid, sensitive and reliable detection of Rice grassy stunt virus. Plant Dis. 74:695698.

9. Hsu, H. T., and Lawson, R. H. 1991. Direct tissue blotting for detection of tomato spotted wilt virus in Impatiens. Plant Dis. 75:292295.

10. Kinard, G. R., Scott, S. W., and Barnett, O. W. 1996. Detection of apple stem grooving viruses using RT-PCR. Plant Dis. 80:616-621.

11. Koenig, R., 1981. Indirect ELISA methods for the broad specificity detection of plant viruses. J. Gen. Virol. 55:53-62.

12. Lin, N. S., Hsu, Y. H., and Hsu, H. T. 1990. Immunological detection of plant viruses and a mycoplasmalike organism by direct tissue blotting on nitrocellulose membranes. Phytopathology 80:824-828.

13. Lommel, S. A., McCain, A. H., and Morris, T. J. 1982. Evaluation of indirect enzyme-linked immunosorbent assay for the detection of plant viruses. Phytopathology 72:1018-1022.

14. Milne, R. G., and Luisoni, E. 1977. Rapid immune electron microscopy of virus preparations. Methods Virol. 6:265-281.

15. Nolasco, G., de Blas, C., Torres, V., and Ponz, P. 1993. A method combining immunocapture and PCR amplification in a microtiter plate for the detection of plant viruses and subviral pathogens. J. Virol. Methods 45:201-218.
16. Powell, C. A. 1987. Detection of three plant viruses by dot-immunobinding assay. Phytopathology 77:306-309.

17. Rowhani, A. 1998. Development of a sensitive colorimetric-PCR assay for detection of viruses in woody plants. Plant Dis. 82: 880884.

18. Rowhani, A., Maningas, M. A., Lile, L. S., Daubert, S. D., and Golino, D. A. 1995. Development of a detection system for viruses of woody plants based on PCR analyses of immobilized virions. Phytopathology 85:347352.

19. Srinivasan, K. G., Narendrakumar, R., and Wong, S. M. 2002. Hibiscus virus $\mathrm{S}$ is a new subgroup II tobamovirus: evidence from its unique coat protein and movement protein sequences. Arch. Virol. 147:1585-1598.

20. Van Regenmortel, H. V., and Buckard, J. 1980. Detection of a wide spectrum of tobacco mosaic virus strains by indirect enzyme-linked immunosorbent assays (ELISA). Virology 106:327-334.

21. Wetter, C., and Conti, M. 1988. Pepper mild mottle virus. CMI/AAB Description of Plant Viruses No. 330

22. Wetzel, T., Candresse, T., Macquaire, G., Ravelonandro, M., and Dunez, J. 1992. A highly sensitive immunocapture polymerase chain reaction method for plum pox potyvirus detection. J. Virol. Methods 39:27-37. 